\title{
Retaining Sport Coaches: A qualitative Assessment of Retention Strategies at Sport Clubs in South Africa
}

\author{
Jhalukpreya Surujlal \\ North West University (Vaal Triangle Campus ), Vanderbijpark, 1900, South Africa \\ Email:Babs.Surujlal@nwu.ac.za. \\ Wynand C.J. Grobler \\ North West University (Vaal Triangle Campus ), Vanderbijlpark, 1900, South Africa \\ Email:Wynand.Grobler@nwu.ac.za
}

\section{Doi:10.5901/mjss.2014.v5n2p651}

\section{Abstract}

Retaining key employees in any organization is critical to the sustainability and long term success of the organization. Sport organizations are no exception. In today's competitive and professional sport environment, coaching resources are vital for the development of future sport 'stars'. Researchers, in their examination of strategies affecting sport performance, conclude that sport coaches are one of the critical success factors in sport performance. In this regard it is of utmost importance that sport organizations retain their staff and specifically coaches to face the challenges in in a highly competitive environment. Coach turnover is a common phenomenon that most sport organizations experience. Trends in coach turnover both nationally and internationally reveal that sport coaches do not stay long in most of the popular sports. The increasing demands of fans and the media place tremendous pressure on both the organization and coach to deliver better results and performance. Unlike many corporate organizations where employees leave due to stressors, lack of commitment in the organization and job dissatisfaction, sport coaches are forced to leave either because fans are dissatisfied with their performance or management perceive that they are not contributing to achieving the objectives of the organization. Currently it is difficult to assess actually what strategies sport organizations use to attract and retain sport coaches. The purpose of this exploratory study was, therefore, to identify strategies sport clubs have in place to retain sport coaches. In order to collect information-rich data, a qualitative research approach utilising telephonic interviews was adopted for the study. The rationale for using this approach lies in the fact that real-life experiences of the respondents involved in the phenomenon being researched would be obtained. Emerging from the content analysis of the data were the following strategies used by sport clubs to retain their coaches: compensation, training and development, participatory decision making, provision of resources, participation in the budgeting process, and contracts. It was concluded that it is important for sport organizations to have an in-depth knowledge of the needs of coaches. While it is important to acknowledge that despite the implementation of various retention strategies, not all sport coaches are guaranteed to remain in the club; it is almost certain that coaches whose needs are not met are more likely to leave.

Keywords: Sport coach, retention, strategies, training and development, decision making, resources, contracts.

\section{Introduction}

Retaining key employees in an organization is critical to the long term sustainability and success of any organization. Sport organizations are no exception. A key human resource in sport organizations is the sport coach whose importance is being increasingly realized (Cushion, Armour \& Jones, 2003). Gould, Greenleaf, Lauer and Chung (1999) argued that the sport coach is one of the most critical success factors in a sport organization. The authors posit that in a highly competitive and professional environment, the coach plays a vital role in assisting the sport organization to achieve its strategic objectives. In recent years the role of the coach evolved immensely and has become more defined (Surujlal \& Dhurup, 2011).

Sport organizations have come to see sport as a means of generating revenue. As a result sport organizations have begun to adopt a business-like approach which applies the various management functions which are routinely used in corporate organizations. These include planning, organizing, budgeting, scheduling, recruiting, public relations and leadership. Sport coaches are, therefore, often called upon to perform the dual role of managers and educators. In a management role they plan, organize, direct and control the activities of their athletes towards the objective of winning. In 
doing this coaches become charged with the responsibility of not only selecting talented players but of also motivating such players to display their peak performance (Surujlal \& Singh, 2007). The Australian Cricket Board (2000) concluded that in the current competitive and professional sport environment, coaching resources are vital in identifying, recruiting, grooming and retaining future sport stars. Given the significant role of the coach in a sport organization it is of utmost importance that sport organizations make every effort to retain this vital human resource to face the challenges in this competitive environment and assist the sport organization achieve a competitive advantage in the sport industry. Sport organizations, therefore, need to take measures to encourage coaches to remain in the organization for as long as possible while their productivity levels are high and they are able to meaningfully contribute to the organization. In this way the pool of available experienced and competent coaches is maintained.

Sport organizations need to realise that by fostering an environment conducive to retaining staff they may create an organization with embedded organizational knowledge and learning. The issue, however, facing sport organizations in recent years is that retaining coaches has become a serious challenge. Sport coaches increasingly face scrutiny from fans, spectators, the media, sponsors and their organizations themselves (Surujlal \& Singh, 2007). This, in many instances, results in increased pressure on coaches which ultimately impacts on their performance. Hence, poor performance which is often linked to the results of the team or athletes is often the reason for coaches either being dismissed or forced to leave the sport organization.

Failure to retain coaches may lead to increased costs in terms of recruitment and training of new incumbents for the sport organization. Additional costs which may be incurred is the development of a successful attraction process to 'lure' good coaches to a sport organization if the current coaches leave. Cuskelly and Auld (2000) argued that the high turnover of sport coaches may seriously hamper the ability of sport organizations to provide high quality and sustained services expected by sponsors, fans, spectators, the media and management. It is therefore important for sport organizations to develop and implement strategies to retain staff and coaches.

From a theoretical perspective there are various factors which contribute to the desire for one remaining in an organization. These factors include intrinsic motivation, a passion for one's job, a sense of belonging to a group, the positive challenge that the job provides, the compensation and recognition one receives for one's achievements and a conducive working environment. Sport organizations have the potential to provide many of these factors to sport coaches.

\section{Literature Review}

Coaches exit sport organizations for a variety of reasons. These include factors such as discriminatory practices, burnout, job dissatisfaction, lack of internal motivation, lack of self- determination, lack of perceived job-relatedness, perceived psychological stressors associated with coaching, reduced passion for the job and a lack of perceived opportunities for personal and professional growth (Acosta \& Carpenter, 1988; Macintosh \& Whitson, 1990; Burke, Joyner, Pim \& Chech, 2000; Deci \& Ryan, 2008; Gray \& Wilson, 2008; Wolfson \& Neave, 2007).

A recent study by Titlebaum, Haberlin and Titlebaum (2009) found that nearly a third of coaches leave their organizations after their first year. The reasons for leaving are not absolutely clear. Bernal, Nix and Boatwright (2012) suggested that to understand behaviour around coaching it is important to address the dynamics of motivation, the factors contributing to stress and anxiety around coaching, and the passion felt for the sport. According to the Self Determination Theory (Deci \& Ryan, 2002), for an individual to experience satisfaction in his/her job three needs, namely autonomy, competence, and relatedness must be fulfilled. In this regard Gray and Wilson (2008) indicated that perceived relatedness and commitment to the sport are the strongest indicators of continuance, followed by intrinsic motivation to continue in a sport profession and commitment to the sport. However, a study by Keyser and Surujlal (2013) found that sport coaches do not experience autonomy in their jobs. The authors strongly advised that sport organizations fulfil this important need so that coaches have more control over their jobs and are able to determine the course of their behaviour. Sport coaches also need to be physically and mentally prepared to handle the psychological stressors associated with sport coaching (Bernal et al., 2012; Burke et al., 2000).

Kanter's (1977) theory of structural empowerment provides an excellent framework for the phenomena associated with negative work behaviours, such as turnover. The theory postulates that the provision of mobility, growth and the ability to mobilize resources may be strong indicators of continuance. This includes issues of discrimination, harassment, race, and sexual orientation. Farrell and Rusbult (1985) include employee job satisfaction, co-worker behaviour, and working conditions as part of their retention model. Pastore (1994) adds giving coaches a voice in department matters, including coaches in the planning process, visiting coaches on a regular basis, maintaining an open-door policy, and 
providing a harassment-free work environment as strong indicators of continuance.

\section{Problem Statement}

Farrell and Rushbult (1985) postulated that the retention function in human resources does not receive as much attention as other functions such as employee selection, training, compensation and performance appraisal. In this regard Inglis, Danylshuk and Pastore (1996) indicated that retaining employees, such as coaches and administrators is critical in preventing undesirable employee turnover and therefore maintaining a consistency in work flow, thereby avoiding the high cost associated with new employee recruitment and training.

The high rate of coach turnover in South Africa is a huge cause for concern (Surujlal, 2004). Considering the important role that the sport coach plays in the identification, recruitment, development and retention of athletes, the existence of academic research focussing specifically on the retention of sport coaches is surprisingly limited. The high turnover of coaches may result in a sport organization's inability to provide a sustained and continuous service to athletes. This may undoubtedly have serious implications for the survival of the sport organization because of its dependence on the success of its athletes.

\section{Purpose of Study}

The purpose of the study was to identify retention strategies that are applied at sport organization from a manager viewpoint.

\section{Research Methodology}

A qualitative research approach utilising semi-structured telephonic interviews was adopted for the study. This approach, which has huge potential to collect information-rich data in a short space of time, provides the opportunity to capture the real-life experiences of the respondents involved in the phenomenon being researched (Patton, 2002). Furthermore, the qualitative approach also allows for the collection of data in the respondent's own words as opposed to restricting respondents to select from fixed responses required in a quantitative approach (Sooful, Surujlal \& Dhurup, 2010).

The advantages associated with using telephonic interviews in this exploratory study are its versatility (Carr \& Worth, 2001) and its ability to produce high quality and detailed data (Sturges \& Hanrahan, 2004) and its ability to obtain precise information. Furthermore, this method is cheaper than most other data collection methods, increases access to geographically disparate subjects, permits increased anonymity, increases interviewer safety and allows the researcher to take notes unobtrusively (Novick, 2008).

\subsection{Sample and procedures}

A purposive sampling procedure was used to recruit respondents for the study. Nine managers who were employed at their respective sport organizations for a period of 3 years and more, and were entrusted with the responsibility of recruitment, selection and retention of staff at the organization were requested to participate in the study. These managers were predicted to stimulate the greatest amount of theoretical return with regard to the phenomenon being researched (Gordon \& Lavalee, 2004).

The following steps were followed prior to the interview: 1) an interview schedule was designed based on the literature; 2) the interview schedule was pre-tested for content validity with two experienced researchers; 3) a pilot test was conducted with four respondents who were demographically similar to the identified sample profile so that the most logical and smooth flowing order of questions could be determined, clarification regarding the wording of the questions could be done and the duration of the interview could be ascertained (Burke \& Miller, 2001); and 4) respondents who consented to being interviewed were provided the interview questions a few days prior to the interview so that richer, more descriptive and precise data were received from them.

A research assistant as well as the principal researcher were present during all interviews. The principal researcher conducted all the interviews to ensure standardisation in the manner the questions were posed. The structure of the interview was designed to make it possible to follow up on issues the respondents brought up, modify the questions depending on the their answers in order to make the interviews conversational and use probes for greater clarity (Smith \& Osborne, 2003). A speaker phone was used to ensure that the interview was heard by the principal researcher as well 
as the research assistant. Notes were taken by the interviewer as well as a research assistant. Immediately after each interview notes were compared to ascertain the accuracy of the responses which were captured. It was noted that theoretical saturation, that is, the point where no new information emerged, had been reached by the $9^{\text {th }}$ interview (Soulliere, Britt \& Maines, 2001).

\subsection{Data analysis}

Data was organised using the immersion and crystallization technique (Crabtree \& Miller, 1999). Following the approach used by Sotiriadou, Shilbury and Quick (2008) the text was examined and crystallized thoroughly. Recurring words, phrases and comments were grouped together and given a conceptual label (strategy). When all the sets of collected data had been coded and categorized, it was possible to note the relationships between all the formulated themes and how they addressed the phenomenon being researched (Henning, Van Rensberg \& Smit, 2004).

\subsection{Ethical considerations}

A number of ethical considerations, some of which are contained in the Belmont report as cited by Maritz and Visagie (2010), were taken into account for this study. Firstly, informed consent was obtained from the respondents in the study. Before the commencement of each interview the principal researcher personally introduced himself to the interviewee. The purpose of the research was clearly explained to each respondent. Assurance was provided that the data collected would be used for research purposes only. Respondents were also assured whatever information received from them would remain confidential and that each individual's anonymity was guaranteed. They were informed that they could withdraw from the study at any stage without any repercussions.

\subsection{Reliability and Trustworthiness}

Patton (2002) opined that since the researcher is the instrument for data collection and analysis in qualitative research, his/her experience is important for the credibility of the data. The principal researcher, having extensive experience in conducting qualitative research interviews, conducted all interviews. Further, with a background of previous research on human resources management in sport the interviewer had adequate contextual knowledge about the challenges that managers in sport organizations experience. This assisted in building rapport with the respondents (Eklund, 1993).

In qualitative research the trustworthiness of data implies the findings are credible, transferable and dependable. In attempting to address the issue of trustworthiness steps to maximise objectivity and minimise bias (Tappen, 2011; Rubin \& Babbie, 2010; Pitney \& Parker, 2009) were taken. This was achieved through member validation. Four respondents were provided with the transcripts of their interviews and requested to comment on the accuracy of the responses which were captured. Feedback received from the respondents indicated that their responses were captured accurately. In addition, an experienced researcher was requested to examine the transcripts and the emergent themes and provide feedback. The comments received indicated that the identified themes were in congruence with the data collected.

\section{Findings and Discussion}

The description and interpretation of the data in qualitative studies are closely linked. The findings of the study and the discussion are therefore integrated in this study. Gustafsson, Hassmén, Kenttä and Johansson (2008) opine that adopting this approach prevents the repetition of explanations. A close analysis of the transcripts revealed the following strategies used by sport organizations to retain coaches: compensation, training and development, participatory decision making, provision of resources, participation in the budgeting process, and contracts. A description of the findings and discussion follows. Excerpts associated with the strategies are provided verbatim from the transcripts.

\subsection{Compensation}

An organization's compensation system is the most powerful tool for managing employee motivation (Griffin, 1990), and cultivating a collaborative work environment (Zobal, 1998). Compensation is the reward given by the organization to its employees in exchange for their work. It deals with every type of reward that individuals receive for performing 
organizational tasks. The compensation package not only critically affects the competitive position of an organization, but also affects employees as it can assist them in meeting many basic needs (Ivancevich, 1998). It is also a sign of acknowledgement of their individual achievements. It enhances their self worth and provides prestige, power and status. Coleman (2002) reported the lack of financial remuneration as one of the reasons for coaches leaving a sport organization. In similar vein, Raedeke, Granzyk and Warren (2000) postulated that if coaches perceived the benefits associated coaching to be high they would display greater commitment and loyalty and would be more likely to remain with the sport organization.

Research by Kim and Cunningham (2005) suggests that adequate financial support contributed to higher levels of job satisfaction. This implies that compensation has the potential to help sport organizations to retain sport coaches. Most of the participants in the study indicated that providing adequate compensation to the sport coaches was one of the most important strategies they used to retain their coaches. In this regard they ensured that their compensation packages were competitive. One of the respondents had this comment regarding the compensation his organization offered:

"We try our best to ensure that the coaches are satisfied with their pay"

\subsection{Training and development}

Training, which is regarded as the cornerstone of human resource management (Heyes, 1998), can be portrayed as a win-win scenario (Skinner, Saunders \& Beresford, 2004) in which both the organization as well as the employee benefit. For the organization training contributes towards a more flexible, committed and motivated workforce. Training develops in employees' psychological well-being and confidence in being able to undertake more challenging tasks (Surujlal \& Keyser, 2013).

Raedeke et al. (2000) found that burnout was a significant factor which contributed to coaches' disengagement from coaching as well as the sport organization. The provision of training and development opportunities may help coaches cope better with burnout. Miller, Salmela and Kerr (2002) acknowledged mentoring as an important source of knowledge and development for coaches. The authors opined that through mentoring coaches are equipped to a level which helps them experience lower levels of stress and burnout. Gilbert and Trudel (2001) suggested that training in the form of coach education which focuses on developing communication skills and skills needed to interact with players, management, fans, spectators, the media and sponsors help coaches to cope better with the perilous nature of coaching. While some of the respondents attributed the lack of training opportunities to affordability, some managers were of the view that training opportunities was an important aspect which should be seriously considered by all sport clubs. This is encapsulated in the following excerpts:

"If we need quality we must help them to develop professionally"

"They need to be trained with the latest technology and equipment"

\subsection{Participatory decision making}

The essence of employees' participation in decision making is found in the notions such as employee participation, participative management, workplace democracy, representative participation and employee empowerment (Robbins, 2003; Robbins, Odendaal \& Roodt, 2007). Access to empowerment structures is associated with the degree of formal or informal power the coach has in the organization (Kanter, 2007). Nedd (2006) differentiates between formal and informal power. Formal power allows flexibility, visibility and crerativity and is central to an organization while informal power is developed through relationships with peers, subordinates and superiors within and outside the organization. Both formal and informal power is essential for sport coaches to function in a sport organization.

Due to increased competition for sponsorship and highly talented athletes at lower costs, and demand for higher performance levels, many sport organizations may be forced to include sport coaches in participation practices with a view to enhancing their commitment (Cummings \& Worley 2008). This may also increase involvement and understanding of workers in an organization (Kenneth, 2008). Podmoroff (2005) argued that through employee participation in decision making employees will benefit by participating jointly with managers and employees in making decisions that affect them and the organization.

Participants in the study echoed the sentiment that the participation of sport coaches in decision making strengthened the relationship between them and the coaches. By involving the coaches in the decision making process they provided coaches with the opportunity to be heard. This is aptly encapsulated in the following excerpts: 
"We want to hear their views"

"They have the expertise and knowledge. They work with the athletes. They know what is required. Why shouldn't they be involved?"

\subsection{Provision of resources}

Kanter (1977) posits that the ability to access necessary materials, supplies, money and personnel needed to meet organizational goals contributes greatly to different behaviours that individuals display. The resources which are important to sport coaches include the supply of athletes/players, the necessary physical infrastructure, equipment, transport and finance. These resources contribute greatly to the level of success that the coach achieves.

The responses of the participants in this study indicate that in most instances the sport club makes every attempt to ensure that the coaches are well equipped with infrastructure, equipment, training kits as well as transport. In addition the sport club makes every possible attempt to attract the best athletes to the club. In some instances where the resources are either inadequate or of a poor quality, they are replaced immediately. This helps the coach to plan and implement training sessions. The participants in the study echoed the following sentiments regarding the provision of resources:

"How are they expected to produce quality if they are not provided the best equipment?"

"If we do not spend money how can we expect results?"

\subsection{Participation in the budgeting process}

Participation in the budgeting process provides employees the opportunity to get involved in and have an influence on the budget setting process (Yeun, 2007). Participation in the budgeting process enables employees to develop mental and emotional feelings that provide them with ownership of budget goals (Ndiwalana, 2009). It influences employee performance, increases an employee's trust, sense of control and commitment to budget goals (Shields \& Shields, 1998) and exerts a motivational effect on employees (Ndiwalana, 2009).

One of the causes of conflict in sport organizations is the lack of transparency in the budgeting process (Meyer \& Surujlal, 2013). From a psychological viewpoint this may pass the message to the coach that s/he is not an important member of the club. Respondents in the study expressed that participation in the budgeting process 'elevated' the position of coaches psychologically. By participating in the budget process coaches are also able to understand the financial position as well as constraints that the club is faced with. This, according to a few of the respondents, helps the coaches understand why their financial demands are sometimes not met. This is aptly encapsulated in the following excerpt:

"If they know the financial position of the club they will provide realistic budgets"

\subsection{Contracts}

Sport organizations in South Africa are largely unregulated in terms of the contract of sport coaches. Most coaches in South Africa enjoy tenure of employment through contractual obligations with their sport organizations (Singh \& Surujlal, 2006). Singh and Moodley (2001) expressed concern that the employment contracts of many coaches do not promise security or stability for coaches resulting in them becoming insecure in their jobs. Surujlal, Singh and Hollander (2004) found that despite the fact that most coaches were consulted in the drawing up of their contracts, most contracts were to the advantage of one party, namely the employer. Respondents in the study commented that while every attempt is made to employ coaches on a full time basis, this is not always possible. In order to retain coaches the sport clubs provide additional benefits in the contacts of the coaches and also make the contracts renewable for additional periods.

\section{Limitations to the Study and Implications for Further Research}

An important limitation of this study is the small sample size that participated. Hence, generalisability of the findings should be approached with caution. Despite this limitation, it was still possible to obtain baseline data on the phenomenon being researched thus providing opportunity for further studies on coach retention strategies. While the qualitative approach highlighted the strategies for coach retention from a manager viewpoint, a mixed method approach with a larger sample over a broader geographical area may provide a greater understanding of coach retention. It may be interesting to obtain coaches' views on what would motivate them to remain at their sport organization and compare the 
viewpoints of managers and coaches.

\section{Concluding Remarks}

The retention of sport coaches in sport clubs requires building loyalty and commitment in sport coaches. Due to the high competition in the sport industry, if coaches are not well cared for and taken seriously, they may be lured in the direction of bigger clubs who are perceived to offer greater benefits. In order to retain sport coaches, it is important for sport organizations to have in-depth knowledge of the needs of the coaches. While it is important to acknowledge that despite the implementation of various retention strategies, not all sport coaches are guaranteed to remain in the club; it is almost certain that coaches whose needs are not met are more likely to leave.

\section{References}

Acosta, R.V. \& Carpenter, L.J. (1988). Women in intercollegiate sport. A longitudinal study-eleven year update 1977-1988. Retrieved from http://eric.ed.gov/ERICDocs/dataiericdocs2sq!!content_storage_Ol/0000019b/80/f// bfl7c.pdf.

Australian Cricket Board (2000). Annual report 1999-2000. Jolimont, Australia.

Bernal, J.C., Nix, C. \& Boatwright, D. (2012). Sport officials' longevity: Motivation and passion for the sport. International Journal of Sport Management, Recreation and Tourism. Retrieved from www.ijsmart.eu.

Burke, K.L., Joyner, A.B., Pim, A. \& Czech, D.R. (2000). An exploratory investigation of the perceptions of anxiety among basketball officials before, during, and after the contest. Journal of Sport Behavior, 25, 11-19.

Burke, L. \& Miller, M. (2001). Phone interviewing as a means of data collection: Lessons learned and practical recommendations [Online journal] Retrieved from http://www.qualitative-research.net/fqs-texte/2-01/2-01burkemiller-e.htm.

Carr, E.C. \& Worth, A. (2001). The use of the telephone interview for research. Journal of Research in Nursing, 6, 511-524.

Coleman, R. (2002). Characteristics of volunteering in UK sport: Lessons from cricket. Managing Leisure, 7, 220-238.

Cummings, T.G. \& Worley, C.G. (2008). Organizational Development and Change (9th ed.). Cengage Learning, Canada.

Cushion, C.J., Armour, K.M., \& Jones, R.L. (2003). Coach education and continuing professional development: Experience and Learning to coach. Quest, 55, 215-230.

Cuskelly, G. \& Auld, C. (2000). Volunteer management programme: Retaining volunteers. Retrieved from http://www.ausport.gov.au /clubs/documents/Vols Retaining.pdf.

Deci, E.L. \& Ryan, R.M. (2008). Facilitating optimal motivation and psychological well-being across life's domains. Canadian Psychology, 49, 14-23.

Deci, E.L. \& Ryan, R.M. (2002). Handbook of Self-determination Research. The University of Rochester Press, Rochester.

Eklund, R.C. (1993). Considerations for gaining entry to conduct sport psychology field research. The Sport Psychologist, 7, 232-243.

Farrell, D. \& Rusbult, C. (1985). Understanding the retention function: A model of the causes of exit, voice, loyalty, and neglect behaviors. Personnel Administrator, 30, 129-140.

Gilbert, W. D., \& Trudel, P. (2001). Learning to coach through experience: Reflection in model youth sport coaches. Journal of Teaching in Physical Education, 21, 16-34.

Gordon, S. \& Lavallee, D. (2004). Career transitions in competitive sport. In T. Morris and J. Summer (Eds.), Sport Psychology: Theory, Applications and Issues (2nd ed) (pp. 584-610). Brisbane: Wiley.

Gould, D., Greenleaf, C., Lauer, L. \& Chung, Y. (1999). Lessons from Nagano. Olympic Coach, 9 (3), 2-5.

Gray, C.E. \& Wilson, P.M. (2008). The relationship between organizational commitment, perceived relatedness, and intentions to continue in Canadian track and field officials. Journal of Sport Behavior, 30, (3), 44-63.

Griffin, R. W. (1990). Management. Houghton Mifflin Company, Boston.

Gustafsson, H., Hassmén, P., Kenttä, G. \& Johansson, M. (2008). A qualitative analysis of burnout in elite Swedish athletes. Psychology of Sport and Exercise, 9, (6), 800-816.

Henning, E., Van Rensburg, W. \& Smit, B. (2004). Finding Your Way in Qualitative Research. Pretoria: Van Schaik.

Heyes, J. 1998. Training and development at an agrochemical plant. In C. Mabey, D. Skinner \& T. Clark. (Eds.), Experiencing HRM (pp 97-112). Sage, London.

Inglis, S., Danylchuk, K.E. \& Pastore, D.L. (1996). Understanding retention factors in coaching and athletic management positions. Journal of Sport Management, 10, 237-249.

Ivancevich, J.M. (1998). Human Resource Management. Irwin/McGraw-Hill, New York.

Kanter, R.M. (1977). Men and Women of the Corporation. Basic Books, New York.

Kenneth, P.J. (2008). Management styles. Retrieved from <http://www.referenceforbbusiness.com

Keyser, E. \& Surujlal, J. (2013). Sport coaches' perception of job autonomy, perceived organizational support and perceived support by supervisors. African Journal for Physical, Health Education, Recreation and Dance, October (Supplement), 145-158.

Kim, J. \& Cunningham, G. (2005). Moderating effects of organizational support on the relationship between work experiences and job satisfaction among university coaches. International Journal of Sport Psychology, 36, 50-64.

Macintosh, D \& Whitson, D.J. (1990). The Game Planners Transforming Canada's Sport System. McGill-Queen University Press, 
Montreal \& Kingston.

Maritz, J. \& Visagie, R (2010). Methodological Rigour and Ethics of Accountability within a Qualitative framework. Paper presented to academic staff at UNISA. Pretoria, March.

Meyer, N. \& Surujlal, J. (2013). Managing conflict at work: A qualitative analysis of municipal sports officers' views in Gauteng province, South Africa. African Journal for Physical, Health Education, Recreation and Dance (AJPHERD), October (Supplement), 101116.

Miller, P.S., Salmela, J.H., \& Kerr, G. (2002). Coaches perceived roles in mentoring athletes. International Journal of Sport Psychology, $33,410-430$

Ndiwalana, J.K. (2009). Budgeting participation, goal commitment and employee performance. Unpublished Masters Dissertation. Makerere University: Kampala, Uganda.

Novick, G. (2008). Is there a bias against telephone interviews in qualitative research? Research in Nursing \& Health, 31, 391-398.

Pastore, D.L. (1994). Strategies for retaining female high school head coaches: A survey of administrators and coaches. Journal of Sport and Social Issues, 18(2), 169-182.

Patton, M. (2002). Qualitative Research \& Evaluation Methods (3rd ed.). Sage, Thousand Oaks, CA.

Pitney, W.A. \& Parker, J. (2009). Qualitative Research in Physical Activity and the Health Professions. Human Kinetics, USA.

Podmoroff, D. (2005). 365 Ways to Motivate and Reward your Employees Every Day with Little or No Money. Atlantic Publishing Group Inc, Florida.

Raedeke, T.D., Granzyk, T.L. \& Warren, A.H. (2000). Why coaches experience burnout: A commitment perspective, Journal of Sport and Exercise Psychology, 22, 85-105

Robbins, S. 2003. Essentials of Organizational Behaviour (7th ed.). Pearson Education, Canada.

Robbins, S.P., Odendaal, A. \& Roodt, G. (2007). Organizational Behaviour -Global and South African Perspectives (3th ed.). Pearson Education, Cape Town.

Rubin, A. \& Babbie, E.R. (2010). Essential Research Methods for Social Work. Cengage Learning, USA: Brooks/Cole.

Shields, J. \& Shields, M. (1998). Antecedents of participative budgeting. Accounting, Organizations and Society, 23(1), 49-76

Singh P.C. \& Moodley, P. (2001). The Job Security of Coaches. South African Journal for Research in Sport, Physical Education and Recreation, 23, (1), 65-73.

Singh, P.C. \& Surujlal, J. (2006). Factors affecting the job satisfaction of South African sport coaches. South African Journal for Research in Sport, Physical Education and Recreation, 28(1), 127-136.

Skinner, D., Saunders, N.K. \& Beresford, R. (2004). Towards a shared understanding of skill shortages: differing perceptions of training and development needs. Education and Training, 46(4), 182-193.

Smith, J.A. \& Osborne, M. (2003). Interpretative phenomenological analysis. In J.A. Smith (ed) Qualitative Psychology: A Practical Guide to Research Methods. London: Sage.

Sooful, A., Surujlal, J. \& Dhurup, M. (2010). Dance and music as mediums for the social integration of children with intellectual disabilities into mainstream society. African Journal for Physical, Health Education, Recreation and Dance (AJPHERD), 16(4), 681-697.

Sotiriadou, K., Shilbury, D. \& and Quick, S. (2008). The attraction, retention/transition, and nurturing process of sport development: Some Australian evidence Journal of Sport Management, 22 (3), 247-272.

Soulliere, D., Britt, D.W. \& Maines, D.R. (2001). Conceptual modeling as a toolbox for grounded theorists. Sociological Quarterly, 42(2), 253-69.

Sturges, J.E. \& Hanrahan, K.J. (2004). Comparing telephone and face-to-face qualitative interviewing: A research note. Qualitative Research, 4, 107-118.

Surujlal, J. (2004). Human resources management of professional sports coaches. Unpublished PhD Thesis. Rand Afrikaans University, Johannesburg.

Surujlal, J. \& Dhurup, M. (2011). Athlete perceptions and preferences of coach behaviour : A qualitatve study of female soccer players. African Journal for Physical Health Education, Recreation and Dance, 17(1), 22-36.

Surujlal, J. \& Keyser, E. (2013). Training of Sport Coaches: Examining the relationship between coach training and demographic variables. African Journal for Physical, Health Education, Recreation and Dance (AJPHERD), October (Supplement), 43-57.

Surujlal, J. \& Singh, P.C. (2007). Concerns of sport coaches: A qualitative study. African Journal for Physical, Health Education, Recreation and Dance (AJPHERD June 2007 Special Edition), 84-96.

Surujlal, J., Singh, P.C. \& Hollander, W.J. (2004). A comprehensive analysis of the job security of professional sports coaches in South Africa. South African Journal for Research in Sport, Physical Education and Recreation, 26(2), 105-116.

Tappen, R.M. (2011). Advanced Nursing Research: From Theory to Practice. Jones \& Bartlett Learning, Canada.

Titlebaum, P.J., Haberlin, N. \& Titlebaum, G. (2009). Recruitment and retention of sport officials. Recreational Sports Journal, $33,102-$ 108.

Wolfson, S. \& Neave, N. (2007). Coping under pressure: Cognitive strategies for maintaining confidence among soccer referees. Journal of Sport Behavior, 30(2), 232-247.

Yuen, D. (2007). Antecedents of budgetary participation' enhancing employee's job performance. Managerial Auditing Journal, 22 (5), 512- 526.

Zobal, C. (1998). The "ideal" team compensation system - an overview: Part 1. Team Performance Management, 4(5), $235-249$. 